\title{
Detection of the etiologic agent of necrotizing hepatopancreatitis in cultured Penaeus vannamei from Texas and Peru by polymerase chain reaction
}

\author{
James K. Loy*, Paul F. Frelier**, Patricia Varner, Joe W. Templeton \\ Department of Veterinary Pathobiology, Texas A\&M University, College Station, Texas 77843-4467, USA
}

\begin{abstract}
Necrotizing hepatopancreatitis (NHP) is a severe bacterial disease that was previously identified solely in cultured Penaeus vannamei, the Pacific white shrimp, from Texas (USA). In January 1993, a disease with similar clinical and histopathologic features to NHP was diagnosed in P. vannamei cultured in Peru. Oligonucleotide primers derived from variable regions V5, V8 and V9 of the $16 \mathrm{~S}$ ribosomal RNA gene sequence enabled polymerase chain reaction (PCR) confirmation of the diagnosis of NHP in both Texan and Peruvian shrimp. The PCR amplification products from the clinical specimens were compared to the PCR amplification product obtained from a sucrose-gradient purified sample of bacteria that was previously used to reproduce NHP. In this study, fingerprinting by restriction fragment length polymorphism (RFLP) analysis of the PCR products was used to compare the isolates. Results indicate that hepatopancreatic lesions are caused by the same bacterium in both Texas and Peru. Negative results were obtained from uninfected shrimp and shrimp infected with Vibro spp., as well as DNA extracted from Brucella abortus, Ehrlichia risticii, Salmonella enteritidis, Agrobacterium tumefaciens and Streptococcus criae.
\end{abstract}

KEY WORDS: Shrimp pathology Hepatopancreatitis PCR $16 \mathrm{~S} \cdot$ Molecular diagnostics

\section{INTRODUCTION}

Necrotizing hepatopancreatitis (NHP) is a severe bacterial disease of cultured Penaeus vannamei, the Pacific white shrimp. Mortality rates attributed to NHP range from 20 to $95 \%$ and the inability to control NHP was, in part, responsible for the abandonment of at least one shrimp farming operation in Texas (USA). The putative etiologic agent of NHP is a pleomorphic, Gram-negative, intracellular, rickettsia-like bacterium (Krol et al. 1991, Frelier et al. 1992, Lightner et al. 1992). Inadequate knowledge of the complex growth requirements of this intracellular bacterium and the absence of shrimp cell lines have prevented in vitro cultivation of the NHP bacterium (Frelier et al. 1993).

The polymerase chain reaction ( $\mathrm{PCR}$ ) is a method for amplification of specified segments of DNA that can be

- Present address: Dept of Experimental Pathology, BristolMyers Squibb, PO Box 4000, F14-03, Princeton, New Jersey 08543, USA.

- Addressee for correspondence

E-mail:pfrelier@vetmed.tamu.edu used to detect pathogenic bacteria (Carl et al. 1990, Hoshina et al. 1990, Ehrlich et al. 1991, Anderson et al. 1992). The PCR assay is extremely useful as a rapid, sensitive and specific means of detecting the presence of fastidious or uncultured bacteria in clinical specimens (Arnoldi et al. 1992, Greisen et al. 1994). Oligonucleatide primers derived from variable regions V5, V8 and V9 of the 16S ribosomal RNA gene sequence (16S rDNA; J. K. Loy et al. unpubl.) enabled confirmation of the diagnosis of NHP in both Texan and Peruvian shrimp by PCR. Using DNA extracted from shrimp tissue obtained from the 2 continents (North and South America) as template DNA in the PCR assay, we were able to amplify a 660 base pair (bp) and a $441 \mathrm{bp}$ NHP bacterium-specific segment of the 16S rDNA. In addition, using restriction fragment length polymorphism (RFLP) analysis the 660 bp amplification product from the clinical specimens was compared to the 660 bp amplification product obtained from a sucrosegradient purified sample of the NHP bacterium that was previously used to reproduce NHP (Frelier et al. 1993). 


\section{MATERIALS AND METHODS}

Bacterial isolation. The positive control consisted of a purified sample of the NHP bacterium that was isolated from shrimp hepatopancreata obtained from a spontaneous outbreak of NHP in Texas-cultured Penaeus vannamei. The NHP bacterium was enriched using a modified Percoll (Pharmacia LKB, Pleasant Hill, CA, USA) density gradient centrifugation as described previously (Tamura et al. 1982, Frelier et al. 1992). Briefly, chilled hepatopancreata were triturated and centrifuged at $200 \times g$ for $8 \mathrm{~min}$ in a Tris-sucrose buffer, $\mathrm{pH} 7.4$, containing $0.033 \mathrm{M}$ Tris-hydrochloride and $0.25 \mathrm{M}$ sucrose, to remove tissue debris. The supernatant fluid was removed and layered on Percoll at a final concentration of $40 \%$ and centrifuged at $25000 \times g$ for $60 \mathrm{~min}$ in an ultracentrifuge. A band of bacteria, formed at the interface of the Percoll, was harvested and frozen in aliquots at $-70^{\circ} \mathrm{C}$. Smears of the harvested band were examined using the Gram-stain and demonstrated small, pleomorphic, Gram-negative bacteria. The purified sample of NHP bacterium, when injected into $P$. vannamei, was demonstrated previously to produce NHP (Frelier et al. 1993).

Extraction of bacterial DNA. Hepatopancreata obtained from Texan and Peruvian shrimp were fixed in $70 \%$ ethanol and triturated prior to processing. The DNA was extracted from either shrimp hepatopancreata or the Percoll-purified bacterial isolate using a similar technique. Briefly, $25 \mathrm{mg}$ of either the fixed, triturated hepatopancreas or the Percoll-purified bacterial isolate was suspended in $250 \mu$ l of digestion buffer (50 mM Tris, $20 \mathrm{mM}$ EDTA, 0.5\% SDS, pH 8.5) in $0.5 \mathrm{ml}$ Eppendorf tubes. Proteinase $\mathrm{K}(7.5 \mu \mathrm{l}$ of a $20 \mathrm{mg} \mathrm{ml}^{-1}$ stock solution) was added to each tube and the solution was incubated at $60^{\circ} \mathrm{C}$ for $2 \mathrm{~h}$ with periodic vortexing of reactants. The tubes were then incubated at $95^{\circ} \mathrm{C}$ for $10 \mathrm{~min}$ to inactivate the proteinase $\mathrm{K}$. The tubes were then microcentrifuged for $3 \mathrm{~min}$ at $13000 \mathrm{rpm}(16000 \times \mathrm{g})$ and $75 \mu \mathrm{l}$ of the supernatant fluid was applied on a CHROMA SPIN TE-100 (Clontech Laboratories, Palo Alto, CA) column and centrifuged in a horizontal rotor according to the manufacturer's protocol. The solution collected by centrifugation was diluted 1:100 and 1:1000 in distilled water (GibcoBRL, Grand Island, NY, USA) prior to being used in the PCR assay.

Polymerase chain reaction. Oligonucleotide primers ranging from 22 to 24 base pairs (Table 1) that recognize variable regions of the $16 \mathrm{~S}$ rRNA gene sequence obtained from sequence analysis of Percoll-purified NHP bacterium (Loy et al. unpubl.) were designed, using a computer software program (MacVector), and manufactured by Advanced DNA Technologies (Texas
Table 1. Primer sequences for polymerase chann reaction

\begin{tabular}{ll} 
Primer name & Primer sequence \\
\hline pf-1 & 5'-ACG TTG GAG GTT CGT CCT TCA G-3' \\
pr-1 & 5'-TCA CCC CCT TGC TTC TCA TTG T-3' \\
pr-2 & 5'-CCA GTC ATC ACC TTI TCT GTG GTC-3'
\end{tabular}

A\&M University, College Station, TX). A combination of the forward primer (pf-1) with 1 of 2 reverse primers (pr-1 and pr-2) yielded overlapping PCR products of $660 \mathrm{bp}$ and $441 \mathrm{bp}$. PCR was performed in $50 \mu \mathrm{l} \mathrm{reac-}$ tions containing $10 \mathrm{mM}$ Tris- $\mathrm{HCl}(\mathrm{pH} 8.3), 50 \mathrm{mM} \mathrm{KCl}$, $1.5 \mathrm{mM} \mathrm{MgCl}, 200 \mathrm{mM}$ deoxynucleotides, $0.5 \mu \mathrm{M}$ of the forward and the parred reverse prumer and 0.03 to $0.3 \mu \mathrm{g}$ of template DNA $(2.5 \mu \mathrm{l}$ of the column-purified DNA previously diluted in distilled water 1:100 or 1:1000). The reactants were heated to $94^{\circ} \mathrm{C}$ in a programmable thermocycler (MJ Research, Inc., Cambridge, MA, USA) prior to adding $1.25 \mathrm{U}$ of Amplitaq DNA polymerase (Perkin-Elmer Cetus Instruments, Norwalk, CT, USA). The final solution was then overlaid with mineral oil. The amplification profile consisted of 35 cycles of $30 \mathrm{~s}$ at $94^{\circ} \mathrm{C}, 30 \mathrm{~s}$ at $58^{\circ} \mathrm{C}$ and $1 \mathrm{~min}$ at $72^{\circ} \mathrm{C}$ with an additional 5 min at $72^{\circ} \mathrm{C}$ following the final cycle. PCR products were examined by electrophoresis in $1 \%$ agarose in TAE buffer containing $0.5 \mu \mathrm{g} \mathrm{mil}^{-1}$ ethidium bromide. The amplified DNA was visualized under ultraviolet light, photographed and the size of the PCR product was estimated by comparison to a 123 base pair standard (GibcoBRL).

RFLP analysis of PCR products. Comparison of the 660 bp PCR products obtained from DNA amplification of clinical specimens (Texas- and Peru-cultured Penaeus vannamei) and Percoll-purified bacterial extracts using restriction endonuclease digestion by DraII, RsaI, HaelII, Sau3 AI and TagI was conducted. Each of the chosen restriction enzymes uses a different frequently occurring recognition site and cleaves the $660 \mathrm{bp}$ PCR product into multiple fragments. A $20 \mu \mathrm{l}$ aliquot of the $660 \mathrm{bp}$ PCR product from the Texas-cultured shrimp, the Peru-cultured shrimp or the Percoll-purified bacterial isolate was digested using restriction enzymes according to the manufacturer's instructions (Boehringer Mannheim, Indianapolis, IN, USA). For RFLP analysis using DraII, Rsâ1, HaelII and Sau3 AI, the reaction was conducted at $37^{\circ} \mathrm{C}$ for $1 \mathrm{~h}$ followed by incubation at $60^{\circ} \mathrm{C}$ for 10 min. RFLP analysis using TaqI was conducted at $60^{\circ} \mathrm{C}$ for $1 \mathrm{~h}$ followed by incubation at $92^{\circ} \mathrm{C}$ for $5 \mathrm{~min}$. The restriction endonuclease digests were then electrophoresed in a $15 \%$ nondenaturing polyacrylamide gel and stained with ethidium bromide. The restriction pattern was examined with an ultra- 
violet transilluminator, the gel was photographed (see Figs. 2 \& 3) and the size of the DNA fragments were estimated by comparison with an MspI DNA digest molecular mass standard (New England BioLabs, Beverly, MA).

\section{RESULTS}

\section{Bacterial isolation}

A distinct white band formed at the interface of the Percoll and the Tris-sucrose buffer following ultracentrifugation of the triturated hepatopancreata. Gramstained smears prepared from this band demonstrated large numbers of small, pleomorphic Gram-negative bacterial rods mixed with cellular debris. Electron microscopic examination of a pelleted fraction of this material demonstrated pleomorphic bacterial rods similar to the small, Gram-negative rods described in spontaneous cases of NHP (Frelier et al. 1992, Lightner et al. 1992). Helical forms of the bacteria (Krol et al. 1991, Frelier et al. 1992, Lightner et al. 1992) were not observed in these Gram-stained preparations or in the electron microscopic analysis of the pelleted subsample.

\section{Polymerase chain reaction}

DNA extracted from the hepatopancreata obtained from Texan and Peruvian shrimp and DNA extracted from the Percoll-purified bacterial isolate were utilized as template DNA for the PCR assay. The primers used in the PCR assay were designed using the sequence obtained from cloning the $16 \mathrm{~S}$ rRNA gene of the Percoll-purified isolate of the NHP bacterium (Loy et al. unpubl.). The PCR primers are designed to hybridize to variable regions in the $16 \mathrm{~S}$ rRNA gene sequence of the NHP bacterium and alignment of the primers using MacVector 4.1 failed to recognize any of the $16 \mathrm{~S}$ rRNA gene sequences in the Genebank and EMBL databases. Two primer-pairs were used to amplify specific segments of the 16S rRNA gene of the NHP bacterium. When PCR primers pf-1 and pr-1 were used to amplify the DNA templates, a characteristic $441 \mathrm{bp}$ product is defined, whereas a $660 \mathrm{bp}$ PCR product is defined when primers pf-1 and pr-2 were used to amplify the DNA templates. A PCR product of the expected length was obtained when DNA extracted from diseased Texas- and Peru-cultured shrimp and DNA extracted from the Percoll-purified bacterial isolate were used as templates (Fig. 1). These PCR primers failed to amplify DNA extracted from normal Penaeus vannamei, DNA extracted from $P$ vannamei infected with a Vibrio spp. and DNA extracted from other pathogenic intracellular bacteria, including: Brucella abortus, Ehrlichia risticii, Salmonella enteritidis, Agrobacterium tumefaciens and Streptococcus criae.

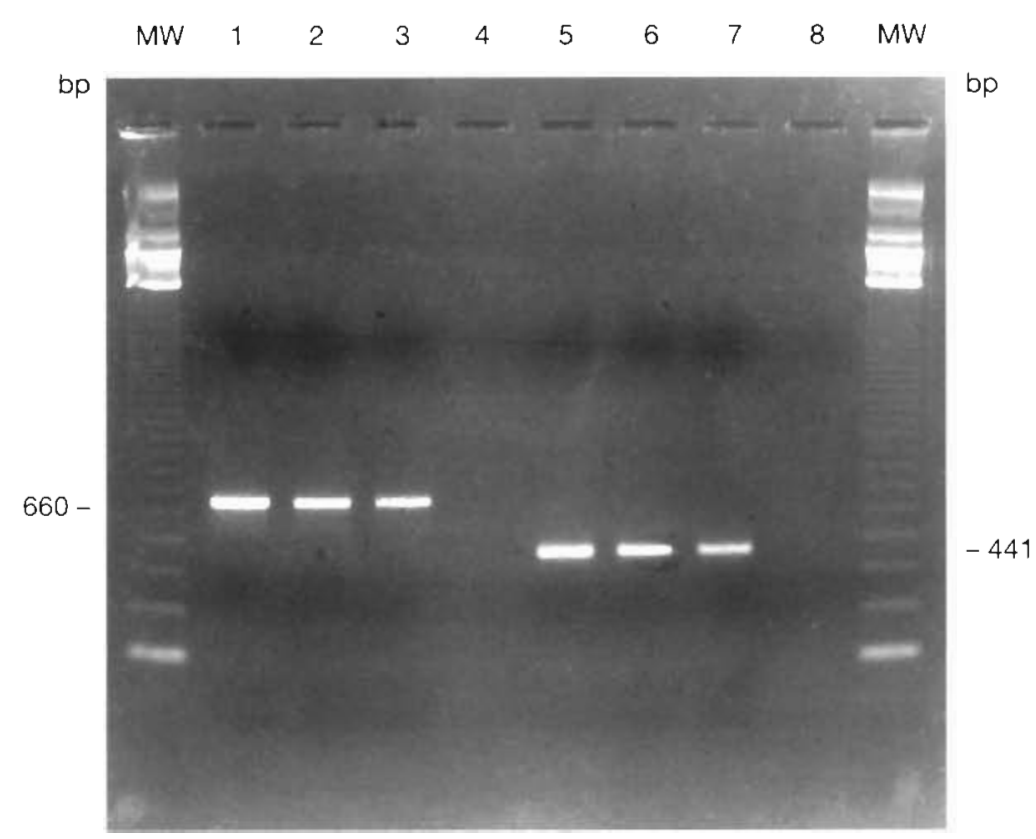

Fig. 1. Agarose gel electrophoresis of PCR products. Primers pf-1 and pr-2 amplified a $660 \mathrm{bp}$ product (lanes 1, 2 and 3) and primers pf-1 and pr-1 amplified a 441 bp product (lanes 5,6 and 7). DNA extracted from Percollpurified NHP bacterium served as template in lanes 1 and 5. DNA extracted from NHP-infected Texas-cultured shrimp served as template in lanes 2 and 6. DNA extracted from NHP-infected Peru-cultured shrimp served as template in lanes 3 and 7. No DNA added in PCR reaction, lanes 4 and 8 . MW: 123 bp molecular mass standards (GibcoBRL)

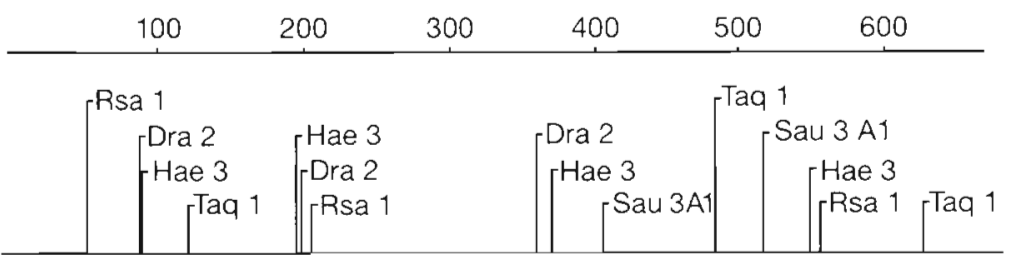

Fig. 2. Map of restriction endonuclease sites, demonstrating relative location of restriction sites in the $660 \mathrm{bp}$ PCR product 


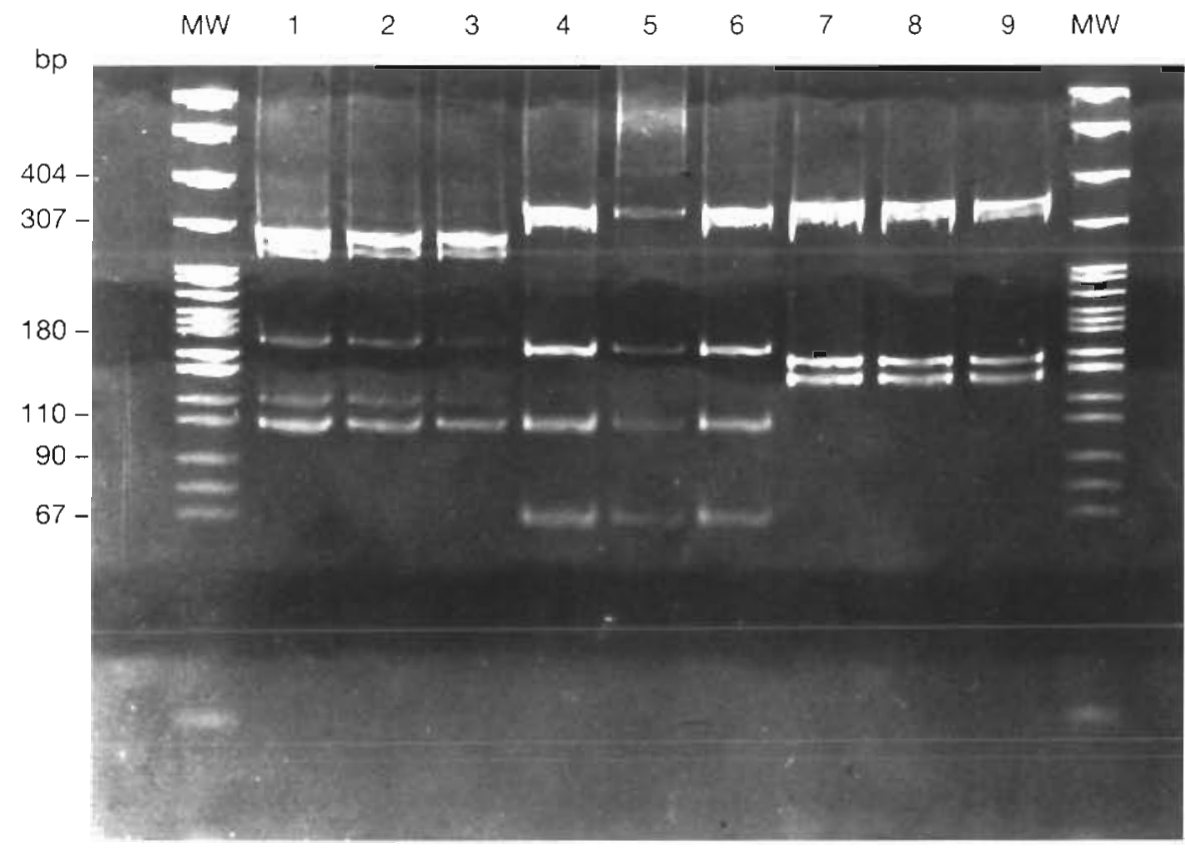

Fig. 3. Polyacrylamide electrophoresis of restriction endonucleasedigested PCR products. Dra II. digested 660 bp PCR product (lanes 1, 2 and 3$)_{i}$ Rsa I digested 660 bp PCR product (lanes 4,5 and 6) and TaqI digested 660 bp PCR product (lanes 7,8 and 9). DNA extracted from Percoll-purified NHP bacterium served as template in lanes 1, 4 and 7. DNA extracted from NHP-infected, Texas-cultured shnmp served as template in lanes 2, 5 and 8. DNA extracted from NHP-infected, Peru-cultured shrimp served as template in lanes 3,6 and 9. MW: MspI DNA digest molecular mass standard

(New England BioLabs)

\section{RFLP analysis of PCR products}

The $660 \mathrm{bp}$ PCR products obtained from the 3 dif ferent amplification reactions were digested with the following restriction endonucleases: Drall, HaellI, RsaI, Sau3 AI and TaqI (see Fig. 2 for map). In each case, the restriction fragment pattern obtained by digesting PCR products corresponded with the pattern predicted by computational analysis of the amplified segment of the $16 \mathrm{~S}$ rDNA of the NHP bacterium. Furthermore, this restriction fragment pattern was identical when bacterial DNA extracted from Texan and Peruvian shrimp and the Percoll-purified bacterial sample was used as the source for template DNA in the PCR assay (Figs. $3 \& 4$ ).

\section{DISCUSSION}

Necrotizing hepatopancreatitis has resulted in severe mortalities of Penaeus vannamei in Texas commercial growout ponds since it was first recognized in 1985 (Johnson 1990). The diagnosis of NHP in cultured $P$. vannamei from the Pacific coast of Peru in January 1993 represents the first time that NHP has been recognized outside the state of Texas. The putative etiologic agent of NHP is a highly pleomorphic, intracellular bacterial organism that has recently been classified as an $\alpha$-Proteobacteria based on comparative sequence analysis of the $16 \mathrm{~S}$ rDNA (Loy et al. unpubl.). However, the in vitro culture requirements for the NHP bacterium are unknown. The NHP bacterium appears to exhibit a complex life cycle with multiple morpho-

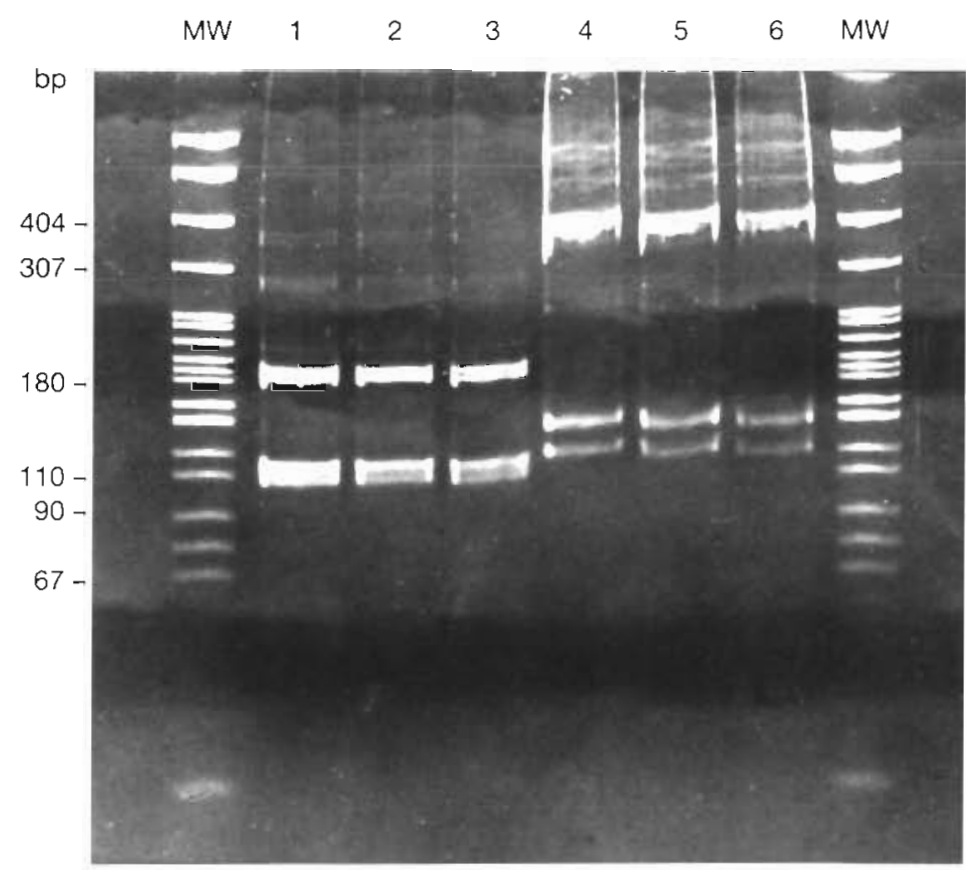

Fig. 4. Polyacrylamide electrophoresis of restnction endonuclease-digested PCR products. HaelI digested 660 bp PCR product (lanes 1, 2 and 3 ) and Sau 3 Al digested 660 bp PCR product (lanes 4,5 and 6). DNA extracted from Percoll-purified NHP bacterium served as template in lanes 1 and 4 . DNA extracted form NHP-infected, Texas-cultured shrimp served as template in lanes 2 and 5 DNA extracted from NHP-mfected, Peru-cultured shrimp served as template in lanes 3 and 6. MW: MspI DNA digest molecular mass standard (New England BioLabs) 
logically distinct developmental stages visualized within infected hepatopancreatic tubular epithelial cells (Lightner et al. 1992). Numerous small, pleomorphic, rod-shaped organisms were observed to occur with helical and intermediate forms of the bacteria (Frelier et al. 1992, Lightner et al. 1992).

Shrimp that develop NHP exhibit the following clinical signs: lethargy, weakness, abdominal muscle atrophy, anorexia and a softened exoskeleton. These signs are nonspecific and do not provide a definitive diagnosis of NHP. Conventionally, the diagnosis of NHP is based on the histologic examination of suspect shrimp for characteristic lesions or the direct visualization of the causative bacterium using special stains or electron microscopy. Herein, we describe a means of detecting the NHP bacterium using a PCR assay. Oligonucleotide primers that hybridize to variable regions of the 16 S rRNA gene were used to obtain specific 660 and 441 bp amplification products using tissue extracts from Penaeus vannamei cultured in Texas and Peru as template DNA. This PCR assay, as applied to tissue extracts of diseased shrimp from Texas and Peru, confirms the diagnosis of NHP in $P$. vannamei from widely distant regions of North and South America. The specificity of the PCR assay was confirmed by amplifying DNA extracted from a Percoll-purified bacterial sample that had been verified to cause NHP in previous experimental transmission studies (Frelier et al. 1993). Also, these primers failed to amplify DNA extracted from a wide range of Gram-positive and Gramnegative bacteria. In addition, no PCR products were obtained when tissue extracts from normal shrimp or tissue extracts from shrimp infected with a Vibrio spp. were used as sources for template DNA. The ability to detect the uncultured bacterial pathogen of NHP in extracts of shrimp tissues by PCR indicates that this PCR assay may be useful as an adjunct to the direct histologic examination of shrimp tissues in NHP diagnosis.

Fingerprinting using RFLP analysis (Clayton et al. 1993) with a battery of 5 different restriction endonucleases was used to compare the PCR products in an attempt to detect differences in the amplification products derived from Texan and Peruvian clinical specimens. The 5 restriction endonucleases (DraII, HaelII, Rsal, Sau3 AI and TaqI) recognize different frequently occurring nucleotide sequences and subsequently cleave the DNA into fragments of varying length based on the incidence of the recognition sequence in the amplification products. The restriction endonucleases were incubated separately with the $660 \mathrm{bp}$ PCR products derived from tissue extracts of shrimp from Texas and Peru, as well as the $660 \mathrm{bp}$ PCR product of DNA extracted from a purified bacterial sample. Each of the 5 restriction endonuclease digests resulted in an identical RFLP pattern irrespective of the source of the template DNA. The PCR amplification of a defined segment of the 16S rRNA gene using primers specific to variable regions (V5, V8 and V9) of the 16S rRNA gene of the NHP bacterium, followed by RFLP analysis of the amplification product, provides evidence that NHP in Texas and Peru are caused by the same bacterium or closely related subspecies. A final determination of relatedness of the bacterium from Texas and Peru is dependent on either the in vitro culture of the bacterium or sequence analysis of the entire 16S rRNA gene of the bacteria from both continents.

The PCR assay described in this report provides a means for early detection of NHP in suspect shrimp. Early diagnosis followed by proper intervention are imperative to the successful treatment of NHP in growout ponds. Currently, we are using this PCR assay in epidemiological studies to identify environmental sources and potential reservoir hosts for the NHP bacterium

Acknowledgements. This research was funded in part under Grant No. H-8158 from the Texas Agriculture Experiment Station, Texas A\&M University System.

\section{LITERATURE CITED}

Anderson BE, Sumner JW, Dawson JE, Tzianabos T, Greene CR, Olson JG, Fishbein DB, Olsen-Rasmussen M, Holloway BP, George EH, Azad AF (1992) Detection of the etiologic agent of human ehrlichiosis by polymerase chain reaction. J Clin Microbiol 30:775-780

Arnoldi J, Schlüter C, Duchrow M, Hübner L, Ernst M, Teske A, Flad HD, Gerdes J, Böttger (1992) Species-specific assessment of Mycobacterium leprae in skin biopsies by in situ hybridization and polymerase chain reaction. Lab Invest 66:618-623

Carl M, Tibbs CW, Dobson ME, Paparello S, Dasch GA (1990) Diagnosis of acute typhus using the polymerase chain reaction. J Infect Dis 161:791-793

Clayton CL, Kleanthoud H, Morgan DD, Puckey L, Tabaqchali S (1993) Rapid fingerprinting of Helicobacter pylori by polymerase chain reaction and restriction fragment length polymorphism. J Clin Microbiol 31:1420-1425

Ehrlich HA, Gelfand D. Sninsky JJ (1.991) Recent advances in the polymerase chain reaction. Science 252:1643-1650

Frelier PF, Loy JK, Kruppenbach R (1993) Transmission of necrotizing hepatopancreatitis in Penaeus vannamei. J Invertebr Path 61:44-48

Frelier PF, Sis RF, Bell TA, Lewis DH (1992) Microscopic and ultrastructural features of necrotizing hepatopancreatitis in Texas cultured shrimp (Penaeus vannamei). Vet Pathol 29:269-277

Greisen K, Loeffelholtz M, Purohit A, Leong D (1994) PCR primers and probes for the 16S rRNA gene of most species of pathogenetic bacteria, including bacteria found in cerebrospinal fluid. J Clin Microbiol 32:335-351

Hoshina S, Kahn SM, Jiang W, Green PHR, Neu HC, Chin N, Morotomi M, Logerfo P, Weinstem IB (1990) Direct detec- 
tion and amplification of Helicobacter pylori ribosomal $16 \mathrm{~S}$ gene segments from gastric endoscopic biopsies. Diagn Microbiol Infect Dis 13:473-479

Johnson SK (1990) Digestive gland manifestations. In: Johnson SK (ed) Handbook of shrimp diseases. Sea Grant Publication No. TAMU-SG-90-601, Texas A\&M University, Galveston

Krol RM, Hawkins WE, Overstreet RM (1991) Rickettsial and mollicute infections in hepatopancreatic cells of cultured

Responsible Subject Editor: J. E. Stewart, Dartmouth,

Nova Scotia, Canada
Pacific white shrimp (Penaeus vannamei). J Invertebr Pathol 57:362-370

Lightner DV, Redman RM, Bonami JR (1992) Morphologic evidence for a single bacterial etiology in Texas necrotizing hepatopancreatitis in penaeus vannamei (Crustacea: Decapoda). Dis Aquat Org 13:235-239

Tamura A, Urakami U, Tsuruhara T (1982) Purification of Rickettsia tsutsugamush by Percoli density gradient centrifugation. Microbiol Immunol 26:321-328

Manuscript first received: May 4, 1995

Revised version accepted: October 30, 1995 